Historic, Archive Document

Do not assume content reflects current scientific knowledge, policies, or practices. 


\section{TRADE, LIST OF}

\section{High Quality Bulbs}

\section{GLADIOLUS BULBS}

Including standard florists forcing varieties, Seed Store varieties and novelties.

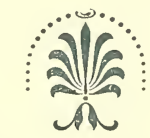

\section{ARTHUR B. MAIN}

WHOLESALE GROWER AND DISTRIBUTOR OF BULBS

MAIL ADDRESS

P. O. BOX 582

SANTA CRUZ, CALIFORNIA WAREHOUSE-25 CHERRY ST. 



\section{GLADIOLUS BULBS}

Prices are per thousand. One hundred bulbs will be sold at the thousand rate where combined with other orders to a total of five hundred or more. For less than this amount add $10 \%$ to the amounts below. Further conditions of offer on back page.

ALICE TIPLADY-Large flowers of brilliant orange saffron. Pri-

BARON HULOT-Deep indigo blue

BYRON L. SMITH-Delicate lavender pink on white ground, lighter in throat. Resembles an orchid..................

CRIMSON GLOW-Glowing crimson with velvety center.

EARLY SUNRISE-Largest brilliant early salmon

ELIZABETH TABOR-Delicate rose pink: lower petals have a crimson blotch. Early _..........

E. J. SHAYLOR-Ruffled flower's of deep rose pink on a tall

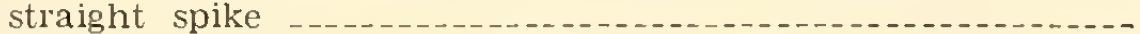

GOLDEN MEASURE-Large golden yellow flowers. A tall sturdy grower

HALLEY — Salmon pink, early

HERADA-Pure glistening mauve

LILY WHITE-Early large white

MRS. FRANK PENDLETON-Pink with carmine blotch at throat

MIRS. FRANCIS KING-Large flowers of a light scarlet or flame red. shaded salmon

MRS. F. C. PETERS-Beautiful shade of rose lilac with crimson

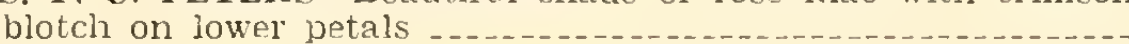

MARIE KUNDERD-Ruffled white, extra primiose yellow throat clear white cream; early

MONA LISA-Ruffled flowers of softest rose pink

MRS. DR. NORTON-Delicate pink with canary yellow throat_.

IMING TOY - Showy deep yellow with buff throat. Prim.

MIXTURE-A special mixture of named varieties mostly listed at a higher price

NIAGARA-Creamy yellow with lavender pencilings.

PRINCE OF WALES-Delicate salmon apricot shade; early

PINK WONDER-Extra large flower with color a shade lighter than Panama. Yellow shading at base of lower petals overlaid with rose featherings

ROSELLA-Rose lavender with large distinct blotch in throat. Striking and beautiful

ROSE ASH-Old rose blended with ashes of rose. Popular......

VIRGINIA-Bright red and one of the best sellers

WIRBRINK-Early flesh pink. A sport of Halley with same characteristics
20.00

25.00

25.00

50.00

60.00

0.00

50.00

25.00

30.00

30.00

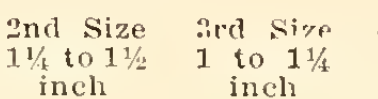

4 th Size

5th Size 6th Size Bulblet. inch

inch

Under

Per

\section{$\$ 20.00 \quad \$ 15.00$}

25.00

20.00

$\$ 10.00$

15.00

$\$ 7.00$

10.00

$\$ 5.00$

$\$ 2,50$

40.00

30.00

20.00

15.00

7.00

3.00

20.00

15.00

25.00

20.00

10.00

15.00

7.00

10.00

5.00

30.00

25.00

20.00

10.00

5.00

7.00

2.00

4.00

15.00

12.00

8.00

15.00

10.00

7.00

40.00

30.00

20.00

5.00

3.00

2.00

15.00

12.00

8.00

15.00

12.00

7.00

5.00

3.00

5.00

1.00

10.00

7.00

2.00

20.00

15.00

12.00

8.00

5.00

3.00

2.00

1.00

30.00

40.00

10.00

5.00

20.00

15.00

10.00

5.00

3.00

$25.00 \quad 20.00$

15.00

10.00

5.00

3.00

20.00

15.00

10.00

8.00

5.00

2.50

30.00

25.00

20.00

15.00

10.00

6.00

3.00

40.00

30.00

25.00

\subsection{0}

15.00

12.00

25.00

20.00

15.00

20.00

16.00

12.00

8.0

5.00

1.00

35.00

25.00

20.00

12.00

9.00

6.00

3.00

$45.00 \quad 35.00 \quad 25.00$
$35.00 \quad 25.00$

18.00

30.00

25.00

18.00

15.00

15.00

10.00

10.00

8.00

3.00

20.00

$16.00 \quad 12.00$

\section{ARTHUR B. MAIN}


The bulbs offered in this list are of first quality and true to name. We will, however, assume no responsibility for the crop, other than to replace bulbs not true to name or refund the purchase prices. All stock is offered f. o. b. Santa Cruz and subject to prior sale and confirmation.

Arthur B. Main.

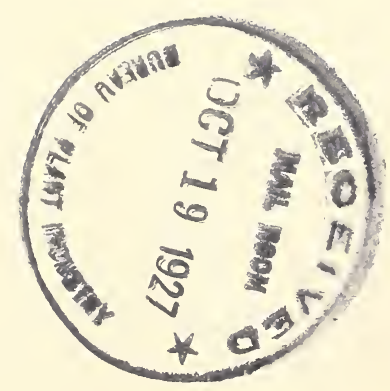

